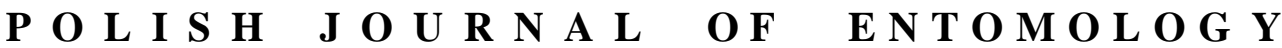

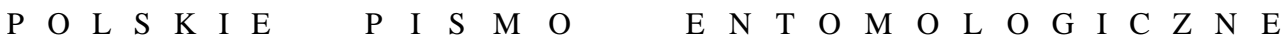

VOL. 86: 39-47

Lublin

31 March 2017

DOI: $10.1515 /$ pjen-2017-0003

\section{The genus Clunio HALIDAY, 1855 from Egypt (Hurghada, Red Sea) with a description of the larva of Clunio sp.1 (Diptera, Chironomidae, Orthocladiinae)}

\author{
Khaled MAHMOUd ABDELSALAM* \\ National Institute of Oceanography and Fisheries, Qayet Bay, El-Anfoushy, \\ Alexandria, Egypt
}

\begin{abstract}
Larval populations of Clunio sp.1 are reported for the first time from marine fouling samples obtained in Hurghada during November 2015. This is a new record for the Egyptian Red Sea fauna. A full structural description of the larva is provided and its local distribution is discussed.
\end{abstract}

KEY WORDS: Clunio sp.1, Diptera, Chironomidae, taxonomy, larva, Red Sea, Egypt, new record.

\section{INTRODUCTION}

Chironomids are common dipterans in aquatic ecosystems. They are ecologically important as consumers of particulate organic matter and are consumed by fish, insects and birds (SoTElO-CASAS et al. 2014). The family Chironomidae is 199-205 million years old (KRZEMIŃSKI \& JARZEMBOWSKI 1999) and has undergone extensive adaptation to occupy a wide range of microhabitats. Although some species live in coastal, marine and terrestrial environments, Chironomidae are most abundant and diverse in freshwater habitats and make up about one-third of the insect species in most lakes and streams (JACOBSEN 2008).

* Corresponding author: kh.abdelsalam@ hotmail.com 
Among the subfamily Orthocladiinae the following genera - Clunio HALIDAY, 1855; Thalassosmittia STRENZKE \& REMMERT, 1957; Halocladius HIRVENOJA, 1973 and the monospecific genus Tethymyia WIRTH, 1949 - appear to be exclusively intertidal (ARMITAGE et al. 1995). However, all members of the genus Clunio settle in the lower midlittoral range of the intertidal zone and in some locations even further down to a depth of $20 \mathrm{~m}$ in the sublittoral (STRENZKE 1960, NEUMANN et al. 1997). There are several populations on the coast of the European Atlantic and the North Sea with a larval habitat in the lower midlittoral (HEIMBACH 1978).

Four species have been reported from the European coast of the Mediterranean Sea: Clunio mediterraneus NeumanN, 1971 (Europe), C. balticus HeImBACH, 1978 (Europe), C. ponticus MichaIlova, 1980 (Europe) and C. marinus HaLIDAY, 1855 (Europe, North Africa, Egypt; SÆTHER \& SPIES 2013). Clunio marinus is known from a number of localities along the European Atlantic coast (OlANDER \& PALMÉn 1968). The metamorphosis and larvae of this species from the Helgoland population (Germany) has been described in detail by STRENZKE (1960). However, larvae of C. mediterraneus have been described by TAŞDEMIR (2010) from Turkey.

Based on the larval stage of Clunio sp.1, this species is considered a new record for the Egyptian chironomid fauna. A full structural description of the larva is provided, and its local distribution is discussed.

\section{MATERIAL AND METHODS}

In November 2015, samples of marine fouling organisms were scraped from beneath the jetty of the National Institute of Oceanography and Fisheries, Red Sea branch, Egypt (Fig. 1).

Samples were preserved in $7 \%$ formalin. During the examination three chironomid larvae were found and isolated for identification. Specimens were cleared in a $10 \%$ solution of potassium hydroxide $(\mathrm{KOH})$ for examination under a compound microscope (model BEL Bio-1-T, with total magnification up to $1000 \mathrm{x}$ ), and photographed with a Nikon digital camera (model D5000). The terminology of the larval morphological features follows SÆTHER (1980). The mentum was illustrated using a PZO camera lucida drawing tube.

Physico-chemical measurements of $\mathrm{pH}$, dissolved oxygen saturation, temperature and salinity were made in situ. The larvae were identified according to STONE \& WIRTH (1947), STRENZKE (1960), CRANSTON et al. (1983) and ANDERSEN et al. (2013). 


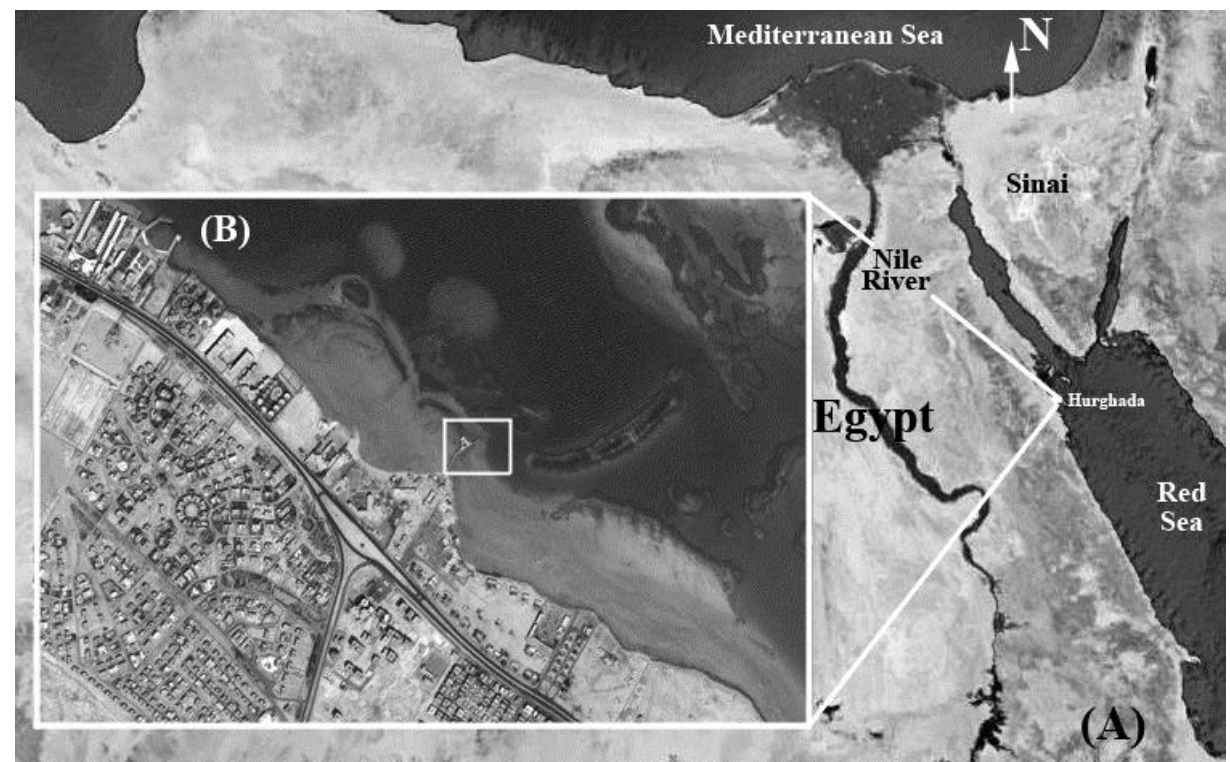

Fig. 1. Map of Egypt. (A). Geographical location of Hurghada on the Egyptian Red Sea. (B). Enlarged map showing the sampling area (the jetty of the National Institute of Oceanography and Fisheries).

\section{RESULTS}

Only three specimens of Clunio sp. 1 were found to be associated with the fouling samples.

\section{SYSTEMATICS}

Genus Clunio HaLIDAY, 1855

Clunio sp. 1 (Larvae, $\mathrm{n}=3$, Red Sea, Egypt)

\section{Description}

Larvae small to medium in size, up to $4 \mathrm{~mm}$ long. Head capsule measuring (240-265 $\mu \mathrm{m})$ in length, yellowish brown in colour. Most body segments whitish with a green tinge. Anterior parapods partially fused basally (Fig. 2); the two posterior parapods separate bearing rows of claws. No body setae. The head capsule with no ventromental plates in the ventral view (Fig. 3). Larvae without procercus and anal tubules but with anal and strong supra-anal setae, measuring 77-83 and 105-113 $\mu \mathrm{m}$, respectively (Fig. 4). 


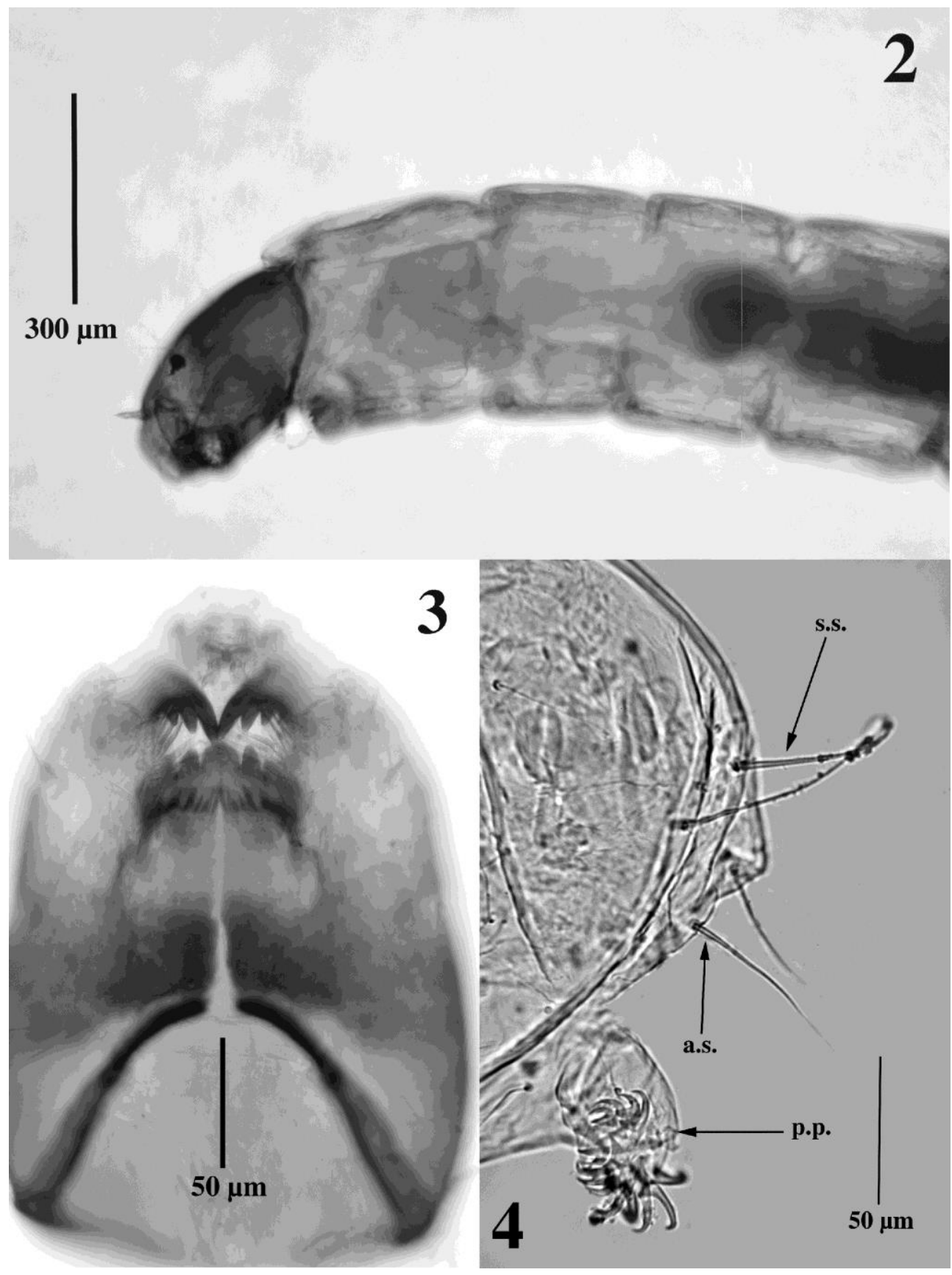

Fig. 2-4. Clunio sp.1: 2. anterior part of larva; 3. ventral view of the head capsule; 4. anal segment showing posterior parapod (p.p.), supra-anal seta (s.s.) and anal seta (a.s.). 


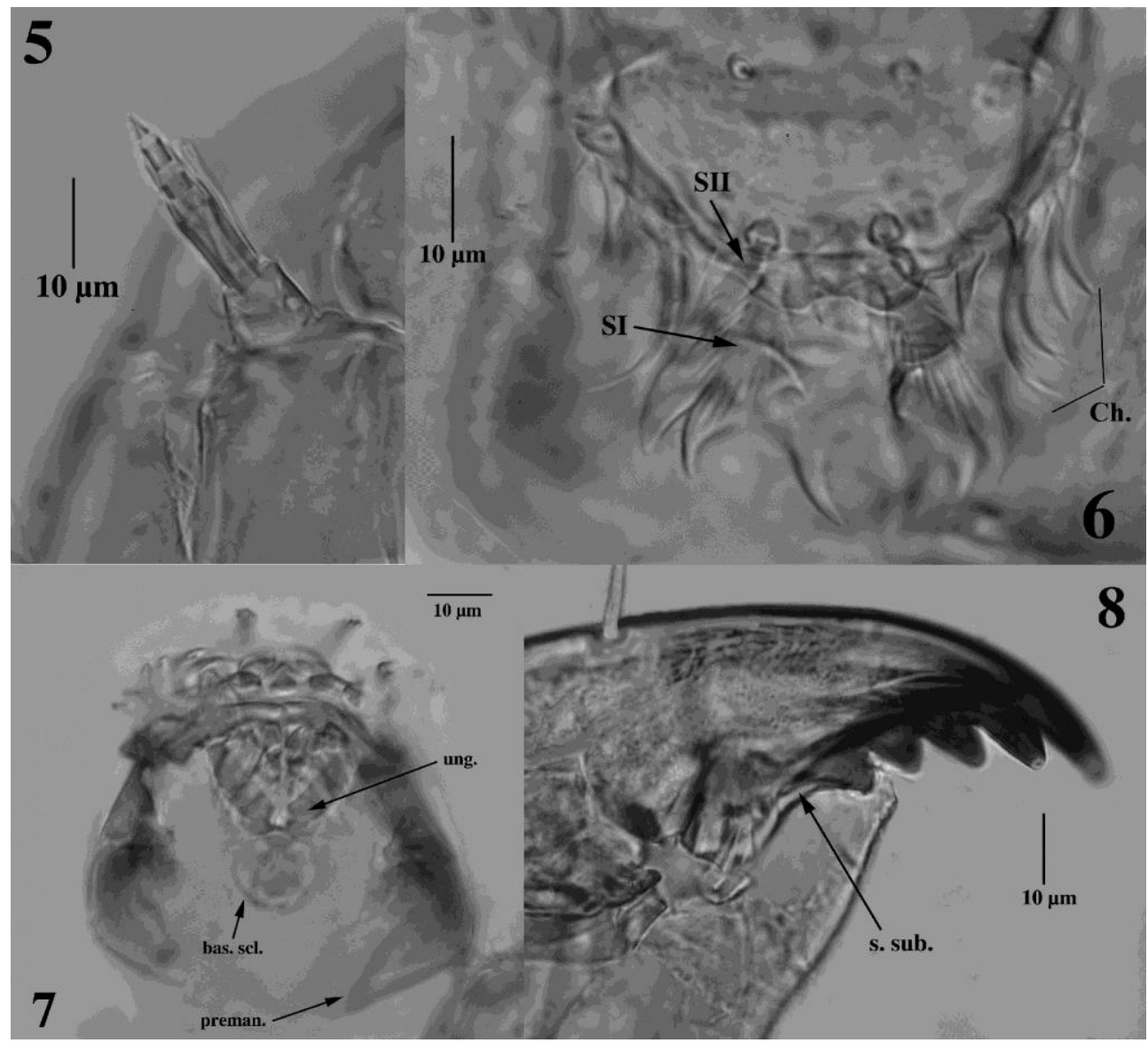

Fig. 5-8. Clunio sp.1: 5. antenna; 6. labrum showing SI, SII plumose setae, chaetae (Ch.); 7. labro-epipharyngeal region showing premandible (preman.), ungula (ung.) and basal sclerite (bas. scl.); 8. mandible showing seta subdentalis (s. sub.).

Head capsule of the larva:

1- Antenna: 5-segmented (Fig. 5), with 4-segmented flagellum. Dimensions of segments: basal segment (segment 1$)$ about as high as wide $(9-11 \mu \mathrm{m})$; segment 2 sub-equal in height $(10-11 \mu \mathrm{m})$ to the first but narrower $(5-6 \mu \mathrm{m})$; segment 3 (width: $3-4 \mu \mathrm{m}$; height: 2-3 $\mu \mathrm{m}$ ) shorter and wider than segment 4 (width: 2-3 $\mu \mathrm{m}$; height: $3-4 \mu \mathrm{m}$ ). Distinct ring organ. Blade not extending further than segment 4. Small style present. Antennal ratio about 0.40 .

2- Labrum: both SI (16-18 $\mu \mathrm{m})$ and SII (11-12 $\mu \mathrm{m})$ are plumose setae (Fig. 6). SI wide, comb-shaped, with 10-12 branches; SII finer, with fewer (6-8) branches. SIII and SIV setae 
normal. Between SI, there are two distal combed scales. The chaetae consist of about 7 lanceolate, mostly unilaterally feathered. Ungula U-shaped with oval or sub-circular basal sclerite. Dark brown premandible with a blunt apical tooth and a broad, blunt inner one; brush absent (Fig. 7).

3- Pecten epipharyngis: complex, consisting of three unpaired, central, basally fused pieces, and paired wide flaky tooth-like elements.

4-Mandible: length of apical tooth of mandible $(17-19 \mu \mathrm{m})$ is less than the combined width of the 4 inner teeth $(31-34 \mu \mathrm{m})$. Seta subdentalis long conical, reaching as far as the last tooth of the cutting edge (Fig. 8). Seta interna consists of 5 strongly feathered branches.

5- Mentum: has one median tooth $(17-19 \mu \mathrm{m})$ which is twice the width of the first (8-10 $\mu \mathrm{m})$ of 4 pairs of lateral teeth. There are weak ventromental plates at the base of the tooth edge, not extending beyond the outer lateral mental tooth. At each side, a distinct, branched seta submenti arises close to the mentum (Fig. 9). These setae are strongly broadened at the base.

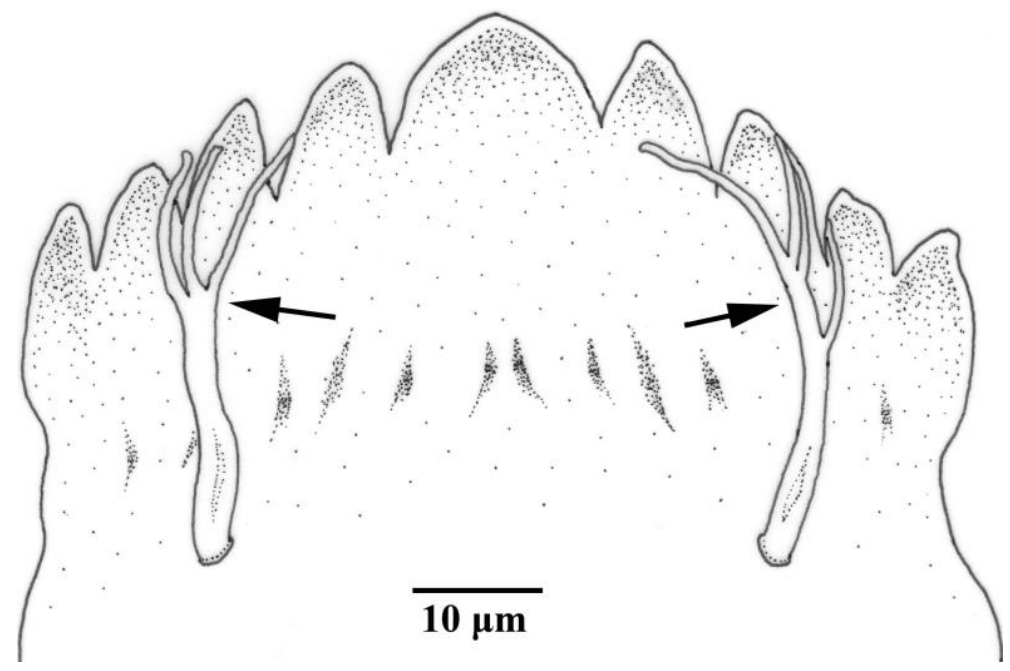

Fig. 9. Clunio sp.1: mentum showing the branched setae submenti (arrows).

\section{Local distribution}

KIEFFER (1925) recorded an adult of Clunio marinus var. aegyptius from Suez (Egyptian Red Sea), at low tide. This taxon was considered a nomen dubium by ASHE \& O'CONNOR (2012). However, the present record of Clunio sp.1 is the first from Hurghada, Egyptian Red Sea. 


\section{DISCUSSION}

Among the marine Orthocladiinae described, larvae of the genus Clunio are characterized by a plumose SII seta (CRANSTON et al. 1983, ANDERSEN et al. 2013), an anal segment with distinct supra-anal setae and 5-segmented antennae (TAŞDEMIR 2010). Larvae of other marine orthoclad genera (Halocladius, Tethymyia and Thalassosmittia) have simple SII setae (CRANSTON et al. 1983).

Larvae of the present study were found associated with fouling organisms in Hurghada (the Egyptian Red Sea). The following parameters were measured in the study area: temperature: $29.9^{\circ} \mathrm{C} ; \mathrm{pH}$ : 8.01 ; dissolved oxygen: $4.19 \mathrm{mg} / \mathrm{l}$; salinity: $39.8 \%$. These environmental parameters are comparable to the physico-chemical measurements made in situ at Antalya Bay, Turkey: temperature: $26.9^{\circ} \mathrm{C} ; \mathrm{pH}$ : 8.09 ; dissolved oxygen: $4.89 \mathrm{mg} / \mathrm{l}$; salinity: 39.3\%, where larvae of Clunio mediterraneus were recorded (TAȘDEMIR 2010). The genus Clunio has a worldwide distribution along temperate and tropical sea coasts (SCHÄRER \& EPLER 2007). As mentioned, four species of genus Clunio have been reported from the European coast of the Mediterranean Sea. However, an adult of Clunio marinus var. aegyptius was previously recorded at low tide from Suez, Egyptian Red Sea (KIEFFER 1925). At the same time, adults of Clunio marinus have been reported off the Egyptian Mediterranean coast (SÆTHER \& SPIES 2013) within the Egyptian exclusive economic zone (at $32.4225^{\circ} \mathrm{N}, 29.6845^{\circ} \mathrm{E}$ ) (K:IChironomidIPENSOFT_php.mht).

According to SCHÄRER \& EPLER (2007), males of Clunio (fully winged) may be able to disperse by flight, but females of Clunio and both sexes of Pontomyia EDWARDS, 1926 (subfamily: Chironominae) are wingless. The carapace of sea turtles may provide a significant means for the long-range dispersal of the larvae of these two genera. The presence of this chironomid genus associated with fouling organisms may suggest that the fouling materials attached to ships' hulls are a dispersal pathway for this genus to the Red Sea.

The setae submenti of the mentum were branched in the specimens examined. However, this character was not mentioned by CRANSTON et al. (1983) or ANDERSEN et al. (2013) in the larval diagnoses of Clunio marinus. The figures in those references showed the Ushaped ungula with a small quadrate basal sclerite. In the present work, the larvae from Hurghada also have a U-shaped ungula but with an oval or sub-circular basal sclerite. Nevertheless, the distinct branched setae submenti of Clunio sp.1 suggest that the specimens from Hurghada might belong to a species new to science, and this will require further investigation.

It is not possible to identify the species from the larval stage only, and more live larvae need to be collected and reared in the laboratory to obtain the pupal or adult stages. Three field trips to Hurghada took place to collect more larvae from and around the same area of 
study, but none were found. According to the available literature, the present record of Clunio sp.1 is the first from Egyptian Red Sea waters, thus representing an addition to the biodiversity of the Egyptian fauna.

\section{ACKNOWLEDGEMENTS}

The author would like to thank Dr John H. EPLER for his valuable comments on the early draft of the manuscript.

\section{REFERENCES}

Andersen T., SÆther O.A., Cranston P.S., Epler J.H. 2013. The larvae of Orthocladiinae (Diptera: Chironomidae) of the Holarctic Region - Keys and diagnoses. [in:] T. ANDERSEN, P.S. Cranston, J.H. Epler (eds.). Chironomidae of the Holarctic Region. Keys and diagnoses Larvae. Insect Systematics \& Evolution Suppl. 66: 189-386.

Armitage P., Cranston P.S., Pinder, L.C.V. 1995. The Chironomidae. The biology and ecology of non-biting midges. Chapman \& Hall, London.

Ashe P., O'ConNor J.P. 2012. A world catalogue of Chironomidae (Diptera) Part 2. Orthocladiinae. Irish Biogeographical Society \& National Museum of Ireland, Dublin.

Cranston P.S. 1995. Introduction. [in:] P.D. Armitage, P.S. Cranston, L.C.V. Pinder (eds.). The Chironomidae: Biology and Ecology of Non-Biting Midges. Chapman and Hall, London, 1-7.

Cranston P.S., Oliver D.R., SÆther O.A. 1983. The larvae of Orthocladiinae (Diptera: Chironomidae) of the Holarctic Region - Keys and Diagnosis. [in:] T. WIEDERHOLM (ed.) Chironomidae of the Holarctic Region, Keys and Diagnosis. 1 - Larvae. Entomologica Scandinavica Suppl. 19: 149-291.

Heimbach F. 1978. Sympatric species, Clunio marinus Hal. and Cl. balticus n. sp. (Dipt., Chironomidae), isolated by differences in diel emergence time. Oecologia 32(2): 195-202.

HiRvenoja M. 1973. Revision der Gattung Cricotopus van DER WulP und ihrer Verwandten (Diptera, Chironomidae). Annales Zoologici Fennici 10(1): 1-363.

JACOBSEN R.E. 2008. A Key to the Pupal Exuviae of the Midges (Diptera: Chironomidae) of Everglades National Park, Florida: U.S. Geological Survey Scientific Investigations Report 20085082. U.S. Geological Survey, Ft. Lauderdale, FL.

KIEFFER J.J. 1925. Chironomides d'Egypte (Dipt.). Bulletin de la Société Royale Entomologique d'Égypte 8 (1924): 244-313.

KRZEMIŃSKI W., JARZEMBOWSKI E. 1999. Aenne triassica sp. n., the oldest representative of the family Chironomidae (Insecta: Diptera). Polskie Pismo Entomologiczne 68(4): 445-449.

Michailova P. 1980. A review of the European species of genus Clunio Haliday, 1855 (Diptera, Chironomidae). Zoologischer Anzeiger 205(5-6): 417-432.

NEUMANN D. 1971. Eine nicht-reziproke Kreuzungssterilität zwischen ökologischen Rassen der Mücke Clunio marinus. Oecologia 8(1): 1-20. 
Neumann D., Kaminsky R., Heimbach F. 1997. Timing of eclosion in marine insects on Mediterranean shores - studies on Clunio mediterraneus, C. ponticus and Thalassomyia frauenfeldi (Diptera: Chironomidae). Marine Biology 129(3): 513-521.

Olander R., PAlmÉn E. 1968. Taxonomy, ecology and behaviour of the northern Baltic Clunio marinus HALID. (Dipt., Chironomidae). Annales Zoologici Fennici 5(1): 97-110.

SÆTHER, O.A. 1980. Glossary of Chironomid morphology terminology (Diptera: Chironomidae). Entomologica Scandinavica Suppl. 14: 1--51.

SÆther O. A., Spies M. 2013. Fauna Europaea: Chironomidae. [in:] T. PAPE, P. Beuk (eds). Fauna Europaea: Diptera, version 2.6. Internet: http://www.faunaeur.org/

SCHÄRER M.T., EPLER J.H. 2007. Long-range dispersal possibilities via Sea Turtle - A case for Clunio and Pontomyia (Diptera: Chironomidae) in Puerto Rico. Entomological News 118(3): 273-277.

Sotelo-Casas R.C., Amílcar leví Cupul-Magaña A.L., Rodríguez-Troncoso A.P. 2014. First record of the genus Clunio (Diptera: Chironomidae) associated with the coral communities at Islas Marietas, Mexico. Revista Mexicana de Biodiversidad 85(1): 14-23.

StOne A., WiRth W.W. 1947. On the marine midges of the genus Clunio Haliday (Diptera: Tendipedidae). Proceedings of the Entomological Society of Washington 49: 201-224.

STRENZKE K. 1960. Metamorphose und Verwandtschaftsbeziehungen der Gattung Clunio HaL. (Dipt.). (Terrestrische Chironomiden XXIV). Suomalaisen Eläin-Ja Kasvitieteellisen Seuran vanamon Tiedonannot 22(4): 1-30.

StrenZKe K., Remmert H. 1957. Terrestrische Chironomiden. XVII. Thalassosmittia thalassophila (BEQU. u. GOETGH.). Kieler Meeresforschungen 13(2): 263-273.

Taşdemir A. 2010. Clunio Haliday, 1855: A New Chironomid Genus for Turkey (Diptera, Chironomidae). Journal of the Entomological Research Society 12(3): 39-43.

WIRTH W.W. 1949. A revision of the Clunioninae midges with description of a new genus and four new species (Diptera, Tendipedidae). University of California Publicantions on Entomology 8: $151-182$.

Received: 27 May 2016

Accepted: 12 October 2016 